\title{
Collaborative approaches to new product development: the case of Russia
}

\author{
Maria M. Smirnova* \\ Graduate School of Management, \\ Saint Petersburg State University, \\ Volkhovsky per., 3, Saint Petersburg, 199004, Russia \\ E-mail: smirnova@gsom.pu.ru \\ *Corresponding author
}

\section{Daria Podmetina and Juha Väätänen}

Lappeenranta University of Technology, P.O. Box 20, 53581, Lappeenranta, Finland

E-mail: daria.podmetina@lut.fi

E-mail: juha.vaatanen@lut.fi

\section{Marko Torkkeli}

Lappeenranta University of Technology, Prikaatintie 9, 45100, Kouvola, Finland E-mail: marko.torkkeli@lut.fi

\begin{abstract}
The paper focuses on collaborative practices applied in new product development (NPD) in Russian firms. Interfirm collaboration is considered as a crucial factor of NPD success in the context of a transitional economy. The research questions are linked to analysis of Russian firms' openness in interaction with external partners in relation to product innovation; whether these patterns are related to the type of product innovation; and to what extent these patterns reflect the strategic orientation of the firm. The empirical basis of the paper is a cross-sectional study conducted on a sample of 223 Russian firms. The results indicate differences in interfirm collaboration in regard to the firm's NPD strategy, the type of product innovation, and the strategic aims of the firm.
\end{abstract}

Keywords: product innovation; new product development; NPD; collaborative innovation; partners; Russia.

Reference to this paper should be made as follows: Smirnova, M.M., Podmetina, D., Väätänen, J. and Torkkeli, M. (xxxx) 'Collaborative approaches to new product development: the case of Russia', Int. J. Entrepreneurship and Innovation Management, Vol. X, No. Y, pp.000-000.

Biographical notes: Maria M. Smirnova is a Senior Lecturer at Saint Petersburg State University, Graduate School of Management. Her research interests include industrial marketing, relationship and interaction in business markets, collaborative innovations and new product development international marketing and quantitative methods. 
Daria Podmetina is a Project Manager in the Department of Industrial Management of the Lappeenranta University of Technology, Finland. Her current research project deals with innovativeness of Russian companies. Her research interests also focus on the emerging economies (especially Russia), international operation of the companies and innovation and technology management. She has published papers in journals such as the Int. J. Innovation Management, Int. J. Business Excellence, Int. J. Technology Marketing and Multinational Business Review.

Juha Väätänen is a Professor of International Business in the Department of Industrial Management at the Lappeenranta University of Technology, Finland. His fields of expertise are international business, transitional economies, country and enterprise competitiveness, and innovation management. He has published papers in journals such as the Int. J. Technology Management, Multinational Business Review, Int. J. Technology Marketing, and Transformations in Business and Economics.

Marko Torkkeli is a Professor of Technology and Business Innovations at the Lappeenranta University of Technology in Kouvola, Finland. His research interests focus on technology and innovation management, strategic entrepreneurship, growth venturing, and decision support systems. He has published papers in journals such as the Int. J. Production Economics, Int. J. Foresight and Innovation Policy, Int. J. Business Excellence, Int. J. Technology Management and Int. J. Technology Intelligence and Planning. He is a member of the editorial boards of the Int. J. of Services Sciences, Int. J. of Innovation Management and Research J. of Business Management. He is a Visiting Researcher at INESC Porto, Portugal, Docent of Technology-based Business at University of Jyväskylä, Finland and Docent of Technology and Innovation Management at Helsinki University of Technology, Finland. He serves as the Director of Publications of the International Society for Professional Innovation Management (ISPIM).

\section{Introduction}

With market globalisation, more and more international players have entered the Russian market, forcing domestic companies 'to innovate or die'. While the long-term success of a firm can depend on developing and introducing new products and services to the market, for the firms in transition economies these processes are often related to substantial barriers. It is obvious for many of them that their own resources and capabilities do not provide a basis for creating positional advantage and contributing to their performance (Day and Wensley, 1988), forcing the market local players to search for potential partners and to support collaborative practices in new product development (NPD).

New products can be considered as the main outcomes of innovation development and a company's growth engine. NPD includes both combination of knowledge in new products, processes, or services (Luecke and Katz, 2003) and commercialisation of new product (Freeman, 1982). Based on these definitions, we consider NPD as a holistic process of innovation starting from idea generation, a development phase, and technology adoption or creation to commercialisation or internal use. 
The research on the product innovations developed by Russian firms does not provide sufficient evidence for explaining the drivers and performance of the NPD process in the context of the Russian economy. Roud (2007) states that the level of innovations in Russian firms is four times lower than in some European countries - e.g., Germany and Sweden. Comparing the BRIC (Brazil, Russia, India and China) economies and their innovation environment, Kaartemo (2009, p.11) reports that "Russia seems to be the worst positioned among the BRIC countries on the innovation front". Both internal issues of the NPD process and external collaboration opportunities may be potential reasons for the lower product innovation performance. Not only path dependence and reliance on planning instead of customer demand, but also lack of infrastructure and financing, and the low level of consumer sophistication can lead to a failure of innovation development - the environment itself causes potential inhibiting factors for firms aiming to develop new products. The reasons for the underperformance of innovation strategies in Russia have mostly been studied at the institutional and macro level, while the drivers and barriers at the firm level are insufficiently presented in existing research.

Both product design and development, and marketing activities of bringing the product to the market may require external collaboration to join the resources, knowledge and competencies of the partners (Amaldoss and Rapoport, 2005). The role of interfirm collaboration in product innovation is highlighted in the literature. As there is research evidence that firms tend to increase collaboration efforts when developing new products (Johnson and Filippini, 2009), there is also evidence that collaboration per se can contribute to the development of product innovation (Walter et al., 2006). The main driver behind collaboration in the product innovation process is the increasing time and cost pressure (Serrano and Fischer, 2007; Kleinsmann and Valkenburg, 2005).The collaborating firms may share resources, knowledge, and know how, and contribute to introducing new technologies or improving the time-to-market of new products or services (Ulaga and Eggert, 2003). While previous studies have focused on the analysis of collaboration practices in the Russian business context, there is hardly any evidence on collaboration in the NPD sphere. Only a few studies providing empirical evidence on collaboration practices exist on the subject. Roud (2007) claims that business groups in Russia can reach superior innovation results by integrating their resources and strategies.

The present study aims at a two-fold contribution. First, it focuses on improving the understanding of the role of interfirm collaboration in NPD, and second, it targets the research context of the Russian transitional economy, which provides further challenges for both NPD and collaboration practices. The research questions of the paper concern the following main issues:

1 Are there any patterns in the behaviour of Russian firms, which would describe their attitude to the firm's openness in interaction with external partners in relation to NPD?

2 Are these patterns related to the type of new product?

3 Do these patterns reflect the strategic orientation of the firm? 


\section{Literature review}

\subsection{Collaboration in NPD}

The research on collaborative innovations addresses the benefits firms can get by relying on collaboration as a way to improve the NPD process (McIvor and Humphreys, 2004; Marshall, 2004). Researchers differentiate between internal and external collaboration for NPD. Internal collaboration focuses mainly on the advantages that can be achieved by integrating the efforts in cross-functional teams (Jassawalla and Sashital, 2003; Johnson and Filippini, 2009). Johnson and Filippini (2009) argue that internal integration is not enough to achieve better results and alignment of internal and external collaboration is required to provide the best chances to improve the innovation capabilities and performance of a firm. The role of external partners in increasing innovation performance is thus crucial for success (Amaldoss and Rapoport, 2005). External cooperation may result in a faster time-to-market with less waste and re-work through the integration of suppliers and customers, regardless of the firm's innovation capabilities level (Johnson and Filippini, 2009; Berger et al., 2005). External collaboration allows for resource contribution by partners, as well as collaborative value creation (Parung and Bititci, 2008; Amaldoss and Rapoport, 2005).

This process of collaboration can be implemented by integrating the contribution of interaction, coordination and communication with different partners or stakeholders (Elias et al., 2002; Hart and Sharma, 2004). The integration of different functional areas is the backbone of innovations (Sarin and Mahajan, 2001), and these functional areas can also be integrated when speaking about various external partners involved. Not all innovations are patented (Botazzi and Giovanni, 2003), and the contribution of external partners is not always easy to assess.

Companies with high skills in NPD cooperation (cooperation capability) have access to a large range of technologies and can manage their resources better (Noori, 1990; Torkkeli et al., 2009). Cooperation in NPD may occur on different levels: strategic (partner selection and management), executive (teams and processes), or infrastructural (Deck and Strom, 2002). Independently from the level of cooperation, firms need to develop specific organisational competencies to support this interaction. The cooperation capability is about how companies develop and manage partnerships (Dyer and Singh, 1998). The core of cooperation capability is the integration of skills and tacit knowledge with external partners. Therefore, companies with better developed cooperation capability are more likely to have stronger relationships with their partners. Companies can develop their cooperation capability over time through daily interaction with their partners. Accumulated collaborative experience is an important explanatory variable for the achievement of successful knowledge flows (Child and Faulkner, 1998). The experience of cooperation with one partner is beneficial when the firm starts to cooperate with another one. Improved cooperation capability depends on the level of trust, knowledge sharing practices, and knowledge absorption capability of partners.

The role of the contribution of external partners and interfirm collaboration cannot be underestimated. Even large companies do not always rely fully on in-house innovations, but tend to increase their involvement in strategic collaboration in innovation activities (Dodgson, 1993, Freeman and Hagedoorn, 1994), and intend to create their own values of cooperation (Smith and Blanck, 2002). Small companies often tend to cooperate in the sphere of NPD in order to overcome a shortage of resources or information (Teece, 
1986), or when they need to outsource some of the production or operational processes, or establish networks with external organisations possessing the needed resources (Rothwell, 1992; Bull, 1993). However, enrolment into networks can also have some disadvantages, like dependency on a weaker partner, or, vice versa, domination by a stronger partner, high cooperation costs, time for management and organisation, as well as risks of lower secrecy (Biemans, 1992).

Inter-organisational cooperation means coordinating the functions of NPD with partners and working out problems, which will bring new solutions and new ideas into the partnership (Uzzi, 1997) and speed up NPD. The synergy effect companies achieve as partners in NPD not only saves time and resources, but decreases the risks of overproduction of components and leaking of information and new ideas, and increases knowledge exchange. The integration of the knowledge of all partners into a unique collective knowledge is the result of successful collaboration. However, not all partnerships in R\&D are successful. Some partnerships fail due to misunderstanding the type of close relationship uniting the partners (Hutt et al., 2000). Besides the substantial contribution of collaborative innovations, the existing research also reflects upon certain barriers in implementing collaborative product innovation, such as dissatisfaction with collaborative efforts, physical barriers, organisational and relational barriers, and knowledge barriers, etc. (Swink, 2006).

Companies can cooperate in NPD with a variety of external partners: suppliers (Parkinson, 1985; Cunningham and Ford, 1993; Håkansson and Eriksson, 1993), competitors (Håkansson, 1989; Clark and Fujimoto, 1991), customers (von Hippel, 1988; Foxall, 1989; Rothwell, 1991; Foxall, 1994), and research organisations (Fowler, 1984; Gemünden et al., 1996), etc. The existing research provides evidence and conceptual development in a number of aspects of interfirm collaboration within the NPD process, such as product and market collaboration (Amaldoss and Rapoport, 2005), co-design and customer-centric collaboration between customers, retailers, and manufacturing (Berger et al., 2005), etc. In particular, client-supplier collaboration has been 'an imperative strategy for NPD' [Lam et al., (2007), p.688]. As Swink (2006) states, while product innovation and supply chain activities have been traditionally separated, collaborative innovation efforts require their integration.

There are a number of classifications of the partners potentially involved in product innovation processes - 'core' and 'fringe' (Hart and Sharma, 2004); vertically forward, vertically backward, horizontal and diagonal (von der Heidt, 2008); and many others. According to Hart and Sharma (2004), it is possible to differentiate between so called 'core' and 'fringe' stakeholders. The role of partners can thus be quite different, although it is mostly assumed that the 'core' ones can contribute more to innovation development. The partners have the opportunity to try, experiment, err, and then seek instruction and feedback from each other. Repeated over time, the parties may feel increasingly confident in their relationship, begin to share mutual understanding, and become more trusting (Ring and Van de Ven, 1994).

Besides joint development, there can be various levels of involving external partners. The relationship marketing literature has contributed to the understanding of the elements of such involvement and the value it can create: including new knowledge and know how, access to third parties, support in innovation development, etc. (Walter et al., 2001). There are some studies which investigate the downstream-upstream cooperation (buyer-supplier cooperation) in order to describe cooperation as the relationship between 
two or more partners in NPD (Appleyard, 2003). Vertical partnerships are project-based collaboration between a manufacturer and a customer or a supplier-partner to develop and commercialise new products (Anderson and Narus, 1990).

The question is, how the firm can manage collaboration with external partners through coordinating the structure of partnerships, involvement of each side, the strategic aims of the firm, and priorities on the level of product innovation (from modifying existing products to radical innovations).

Managing collaborative innovation processes increases the complexity of coordination (Marshall, 2004). Other factors of successful collaboration are communication patterns and skills matching (Bjelland and Wood, 2008). Bonney et al. (2007, p.396) name the following factors of successful collaborative innovation: shared vision, compatible structures and processes, opportunities for mutual benefits, presence of trust, and commitment. Based on the classification of multiple partners in external innovation collaboration, we thus assume that:

P1 There are certain patterns in the way firms are selecting external partners to be involved in NPD processes.

The partners vary in their ability to contribute to NPD. Kotabe and Swan (1995) have investigated the role of strategic alliances in high-technology NPD. They argue that there is a difference in the degree of innovativeness of the products that can be explained by whether the cooperating partners are associated to the firm by a horizontal linkage or a vertical linkage, and hypothesise that the products of horizontally cooperating firms are likely to be more innovative than products developed in case of vertical cooperation. Kotabe and Swan claim that horizontal collaboration tends to increase the level of innovativeness of products more than vertical collaboration or a single-firm strategy. The more successful firms collaborate with diverse partners in a range of innovation types. When discussing the role of external partners, it is important to mention the dichotomy proposed and discussed by Berthon et al. (1999). This approach differentiates between firms 'serving' existing markets and 'creating' new offerings, in many cases exceeding market expectations. While the first firms will mostly follow the requests of partners in the network to modify existing products or adapt them to partners' needs, the latter ones will mostly use knowledge and insights from partners to foresee the direction of innovations that will guarantee future advantages. These innovations will be more radical by nature.

If the sources of innovation are more likely external, the more radical the innovation can be (Georghiou et al., 1986; Gobeli and Brown, 1987; Meyers and Athaide, 1991; Yli-Renko et al., 2001). Incremental innovations owe most to innovative activity within an established line of productive activity. The most novel innovations depend on external technological developments which change a given design configuration. Intermediate forms of innovation may depend on either internal or external sources (Georghiou et al., 1986). There is a significant positive association between a firm's involvement of key stakeholders in product innovation and product innovation performance (von der Heidt, 2008). Therefore, we develop our hypothesis as follows:

P1a The patterns of external NPD-related collaboration are linked to the type of product innovation for the firm: radical new product innovations will require closer collaboration with a wider circle of partners. 
Differences in the technical capabilities, role and objectives between the parties in a collaborative innovation process might lead to a potential conflict, and thus these differences, conflicts and interdependence are substantial elements of collaboration (Lam et al., 2007). Communication and information exchange are particularly important for multi-sided collaboration in NPD to achieve the primary objective of risk reduction that cannot be performed without risk assessment and communication between the sides (Kleinsmann and Valkenburg, 2005). The impact of risk assessment and alignment between the parties would lead to an improved speed of decision, expansion of scope of collaboration and degree of concurrency (Kayis et al., 2007). Parung and Bititci (2008) identify effective support from senior management, understanding the mission and objectives of collaboration, leadership, and excellence of partners as key factors of innovation collaboration success. The extent of tacit knowledge exchange, necessary for joint value creation (Parung and Bititci, 2008) depends on the parties' ability to apply information technology to support interaction and facilitate communication (Seshasai and Gupta, 2009).

\subsection{NPD in Russia: challenges and perspectives}

The existing research does not provide sufficient evidence on product innovation development in Russia. There is some research, however, focusing on the success factors and barriers to product innovation success. According to Kadochnikov et al. (2003), product innovations by Russian firms are mainly forced by competition with domestic companies, change in market demand or appearance of new segments, and at the same time these are product innovations which are reported to have the most significant impact on firms' performance. Analysing the situation with innovations in Russia, Roud (2007, p.5) reports that “firms' innovative activities are constrained by lack of financial resources, flourish under the conditions of governmental support, are mainly oriented on technology purchasing rather than development and are somewhat constrained by lack of human resource.”

Interfirm collaboration in the context of the Russian market has been more substantially studied (Salmi, 2004; Jansson et al., 2007; Johanson, 2008). On the other hand, hardly any evidence can be found in the existing literature on collaboration in NPD with participation of Russian firms. International companies might find it difficult to collaborate with Russian partners in the field of product innovations. Among the main problems of cooperating with Russian partners in the international collaboration perspective, the following reasons may be named: problems in commercialisation of Russian innovations because of weakness of intellectual property rights protection transparency, lack of financing of innovation developments and start-ups, low level of English proficiency and international communication, bureaucracy, and corruption (Koponen, 2009). Lack of trust and commitment, and low understanding of how the value might be distributed provide substantial barriers to collaboration (Bonney et al., 2007). Besides, according to a World Bank study, the productivity of Russian R\&D is very low in international comparison (Schaffer and Kuznetsov, 2007).

In previous studies, the authors have investigated the differences in NPD between Russian and foreign companies operating in Russia. More than one third (36\%) of foreign companies have introduced new products in the last three years compared to $26 \%$ of domestic companies. Foreign companies are more likely to cooperate with external 
partners in the product development phase (Torkkeli et al., 2009). The results of previous studies indicate challenging trends related to product innovations in Russia. The pressure from international market players has a strong stimulating effect, driving the need for more radical product innovations. Firms perceiving this challenge as important will have to change their strategy and search for ways to innovate through collaboration. The ability of Russian firms to be successful in product innovations by adopting an in-house innovation model is questionable. Nevertheless, existing studies report that the driver for product innovations is not competition with international companies, but rather horizontal competition with domestic firms (Kadochnikov et al., 2004). The same study implies that vertical collaboration in NPD is a unique facilitator of product innovation in Russia. Following the logic of existing research, we imply that just those Russian firms that follow a strategic orientation at NPD leadership will be able to develop successful collaboration, both with domestic and international partners.

P2 The intensity of external NPD collaboration will directly depend on the prioritisation of NPD-related strategic aims.

\section{Research design}

The empirical study was conducted during December 2007 to February 2008. 223 Russian firms from various industries agreed to participate in the study through face-to-face structured interviews (average duration 1.5 hours). The key respondents were representatives of the marketing department or top management of the firm. A number of criteria were used to select the firms, including region, industry, and annual revenue of the company. The sampling method was based on the stratified sample approach, which means not a representative, but a meaningful structure of the sample. The data on the firms were taken from the database on registered Russian firms (SKRIN). One of the key criteria was the readiness of the firm to provide information, which may have been a potential limitation of the sampling method, as the firms less interested in NPD may have rejected participating in the study. On the other hand, analysis of the reasons for rejection of participation in the survey reflected mostly lack of time by potential respondents, not lack of interest in the study.

Due to the selection of key respondents it was possible to obtain information on collaboration with external partners in relation to NPD processes. Key information on the sample is presented in Table 1. The average age of the firms in the sample was 29 years, varying from one to 134 years. The relationship between products and services in the firms' portfolio varied from $0 \%$ to $100 \%$ with the average of $73 \%$ products and $27 \%$ services. The relationship between serving industrial and consumer markets also varied from $0 \%$ to $100 \%$, the average of $56 \%$ firms serving industrial markets and $44 \%$ consumer markets. Out of the 223 firms in the sample, $1.8 \%$ assessed their economic situation as 'near bankruptcy', $4.9 \%$ as 'bad', $29.1 \%$ - as 'satisfactory', $46.6 \%$ as 'good', and only $10.3 \%$ as 'excellent.' 
Table 1 Sample description

\begin{tabular}{lc}
\hline Key industries & $\%$ \\
\hline Machinery & 19.4 \\
Food industry & 13.1 \\
Production of construction materials & 11.6 \\
Chemical industry & 10.6 \\
Light industry & 8.6 \\
Woodworking industry & 6.8 \\
ICT & 6.8 \\
\hline Annual sales (2006) & \\
\hline Less than 100 million RUR & 51.6 \\
100-500 million RUR & 24.7 \\
500 million to 1 billion RUR & 11.6 \\
More than 1 billion RUR & 12.1 \\
\hline Type of firm & \\
\hline Public companies & 35.4 \\
Limited companies & 59 \\
State companies & 4 \\
Other & 1.6 \\
\hline Number of employees & \\
\hline Less than 50 & 12.3 \\
From 50 to 100 & 14.6 \\
From 100 to 500 & 34.7 \\
From 500 to 1,000 & 17.4 \\
More than 1,000 & 21.0 \\
\hline
\end{tabular}

\subsection{Measurements}

A number of variables related to collaboration in NPD were used in the study. The key respondents had to identify the extent of involvement of ten key groups of external partners in NPD, including suppliers in Russia, suppliers abroad, customers in Russia, customers abroad, intermediaries, shareholders, competitors, consultants, research organisations and partners in joint ventures.

The type of NPD strategy was defined on the basis of three options: in-house NPD, collaborative NPD and outsourcing.

- Involvement of external partners. A dichotomous question was used to measure whether a certain group of external partners had contributed to the NPD process. Before indicating the involvement of external partners, the respondents answered preliminary questions about their NPD strategies, including aims, the criteria for NPD success assessment, and the role of collaboration in their NPD practices. Thus, the role of the involvement of external partners was analysed in relation to the overall NPD strategy and its performance. 
- Type of product innovation. All product innovations were grouped into modifications of existing products, products new to the firm, new for the Russian market, and new for the industry. This approach allowed indicating the level of product innovation in the firm. This measure was considered as an ordinal scale, ranging from the least radical product innovation (modification of an existing product) to the most radical one (introduction of a product new to the industry).

- Strategic aims. A list of strategic aims was used to measure the priorities of the firms in the sample, including three aims in the field of product innovation: 'leadership in NPD', 'improvement of time of product development', 'improvement of time-to-market'. All the aims were assessed on a five-point Likert scale with question anchors from 'not important at all' to 'highly important.'

\section{Key findings}

The analysis of the role of external NPD collaboration depends on the role and importance of product development activities. According to the results of the study, $88.8 \%$ of the firms in the sample had introduced new or substantially modified products over the last three years. It is important to note that the aims in the field of NPD were not ranked high by the firms in the sample. Following the market dynamics and constant growth of the Russian market over the last years, the firms in the sample prioritised growth in sales and in market share as their primary aims. Only $58.3 \%$ of the firms in the sample assessed the aim to obtain NPD leadership as 'high' and 'very high'; only $48.4 \%$ of firms reported to prioritise the time of NPD reduction, and $45.7 \%$ time-to-market reduction. The results on the aims ranking reflect an extensive growth-oriented strategy in the firms in the sample, while factors critical for long-term growth, such as speed of NPD, time-to-market and leadership in NPD were left in the end of strategic aims ranking.

\subsection{Type of product innovation and NPD collaboration}

The products introduced over the last three years by the firms in the sample varied from modifications of existing products to radical product innovations, introducing new-for-the-industry products. $80.1 \%$ of the firms had introduced products new for the firm, $71 \%$ modifications of existing products, $39.8 \%$ products new for the domestic market, and $23.7 \%$ products new for the industry in the whole. According to the results, most firms combined types of product innovations.

As the results indicate (Table 2), the firms in the sample combine three key approaches to NPD - in-house NPD, collaborative NPD and outsourcing of NPD, while the dominating approach is based on the firm's own R\&D potential ( $95 \%$ of the firms) and the in-house product innovation model (39\%). By contingency analysis with the type of product innovation, it is possible to identify some patterns in NPD approaches in Russian firms. The role of in-house NPD is crucial for Russian firms, independent on the type of product innovation. The highest share of firms applying collaborative product innovation practices can be found in the group of firms introducing the most radical product innovations - new at the industry level. The role of outsourcing in NPD is similar across all the groups. The results indicated that the firms in the sample are mostly 
combining their approaches to product innovation, using both in-house NPD in combination with collaborative NPD and/or outsourcing.

Table 2 NPD approach and type of product innovation: multiple response analysis

\begin{tabular}{lccccc}
\hline & \multicolumn{5}{c}{$\begin{array}{c}\text { Type of product innovation, \% of firms } \\
\text { (multiple responses were possible) }\end{array}$} \\
\cline { 2 - 6 } & $\begin{array}{c}\text { New for } \\
\text { the firm, \% }\end{array}$ & $\begin{array}{c}\text { New for the } \\
\text { domestic } \\
\text { market, } \%\end{array}$ & $\begin{array}{c}\text { New for the } \\
\text { industry, \% }\end{array}$ & $\begin{array}{c}\text { Modification } \\
\text { of existing } \\
\text { products, \% }\end{array}$ & $\begin{array}{c}\text { All new } \\
\text { products,\% }\end{array}$ \\
\hline In-house NPD & 97 & 97.2 & 100 & 92.3 & 94 \\
Collaborative NPD & 39 & 53.5 & 61 & 46.5 & 42.7 \\
Outsourcing & 9 & 9.9 & 7 & 10.8 & 10.5 \\
\hline
\end{tabular}

Notes: *Each column indicates the share of firms in percentage. The sum of percentages is not equal to 100 , because multiple response analysis has been used, and the respondents could give more than one answer to the question.

\subsection{The role of type of product innovation in determining the type of partners involved}

Following the categories of product innovation proposed above - from modification of existing products to development of radically new products, the next table introduces the results of external partners' involvement in the NPD processes of Russian firms, grouped by the type of product innovation. The results of the analysis (see Table 3) indicate that there are particular patterns of collaboration with external patterns when comparing the firms on the type of product innovation.

Table 3 Involvement of external partners, depending on type of product development $(\mathrm{n}=223)$

\begin{tabular}{lccccc}
\hline $\begin{array}{l}\text { Types of new product } \\
\text { innovation }\end{array}$ & $\begin{array}{c}\text { All firms in } \\
\text { the sample }\end{array}$ & $\begin{array}{c}\text { Modification } \\
(n=25)\end{array}$ & $\begin{array}{c}\text { New for } \\
\text { the firm } \\
(n=76)\end{array}$ & $\begin{array}{c}\text { New for } \\
\text { Russia } \\
(n=41)\end{array}$ & $\begin{array}{c}\text { New for the } \\
\text { industry } \\
(n=44)\end{array}$ \\
\hline Suppliers in Russia & 35.9 & 40.0 & 34.2 & 43.9 & 34.1 \\
Suppliers abroad & 24.2 & 24.0 & 19.7 & 26.8 & 40.9 \\
Customers in Russia & 47.1 & 56.0 & 39.5 & 61.0 & 56.8 \\
Customers abroad & 23.3 & 16.0 & 19.7 & 29.3 & 38.6 \\
Intermediaries & 30.5 & 40.0 & 25.0 & 34.1 & 38.6 \\
Competitors & 29.1 & 33.3 & 27.6 & 19.5 & 45.5 \\
Partners in joint ventures & 26.9 & 36.0 & 23.7 & 24.4 & 40.9 \\
Consultants & 34.5 & 36.0 & 30.3 & 29.3 & 59.1 \\
External research & 29.1 & 44.0 & 21.1 & 29.3 & 47.7 \\
organisations & 32.7 & 36.0 & 27.6 & 29.3 & 47.7 \\
Shareholders & & & & & \\
\hline
\end{tabular}

Russian firms introducing modifications of existing products only have higher than average involvement of customers, intermediaries, suppliers and external research organisations. The product innovation process in these firms is pulled by the 
demand-side, forcing modifications to existing products. This is a certain 'serving the market' strategy, as opposite to 'creating the market' in terms of the dichotomy defined by Berthon et al. (1999).

The firms introducing the most radical product innovations (products new at the industry level) have the highest share of involvement of suppliers and customers from abroad, competitors, partners in joint ventures, consultants, external research organisations, and shareholders. These firms seem to follow the strategy of a more intensive collaboration, not only focused on some 'core' stakeholders, but searching among a broader circle of potential contributors (Hart and Sharma, 2004). These firms seem to be better prepared for global integration, as the share of international external partners in NPD is the highest for this group of firms across the sample.

In the sample, the involvement of partners in vertical channels is the most intensive customers, suppliers and intermediaries. These results fully support the evidence from previous studies on Russian firms, as presented by Kadochnikov et al. (2004).

\subsection{The role of strategic aims in NPD collaboration}

The creation of long-term advantage requires not only tactical steps, but also existence of long-term orientation in strategic aims. As reported above, the role of strategic aims related to product innovation was relatively weak for the firms in the sample. Only half of firms assessed these aims as 'important' or 'very important'. Based on this criterion, the firms were divided into two groups on the basis of the mean value of three NPD-related aims - 'leadership in NPD', 'time-to-market reduction' and 'time of NPD reduction'. One group contains the firms with the mean on all the three aims below the average, and the other group includes the firms with the mean on these aims above the average.

The results of the group analysis indicate that strategically NPD-oriented firms interact indeed more actively with most groups of potential external partners, particularly with competitors, partners in joint ventures, consultants and external research organisations. At the same time, in regard to some of the groups - customers, shareholders, and intermediaries - this difference is not substantial.

Table 4 Involvement of external partners, depending on NPD aims $(n=223)$

\begin{tabular}{llccc}
\hline & All firms & $\begin{array}{c}\text { High importance } \\
\text { of NPD aims }\end{array}$ & $\begin{array}{c}\text { Low importance } \\
\text { of NPD aims }\end{array}$ \\
\cline { 2 - 5 } & Involvement of... & \% firms & \% firms & \% firms \\
\hline 1 & Customers in Russia & 47.1 & 46.6 & 50.5 \\
2 & Suppliers in Russia & 35.9 & 37.9 & 33.7 \\
3 & Consultants & 34.5 & 40.5 & 26.3 \\
4 & Shareholders & 32.7 & 35.3 & 31.6 \\
5 & Intermediaries & 30.5 & 31.9 & 29.5 \\
6 & External research organisations & 29.1 & 32.8 & 24.2 \\
7 & Competitors & 28.8 & 32.8 & 23.2 \\
8 & Partners in joint ventures & 26.9 & 32.8 & 20.0 \\
9 & Suppliers abroad & 24.2 & 26.7 & 22.1 \\
10 & Customers abroad & 23.3 & 25.0 & 22.1 \\
\hline
\end{tabular}


The role of the NPD-orientation of a firm was also checked by analysing the share of each type of product innovation, developed by the firms with higher or lower importance of leadership in NPD. The results presented in Table 5 indicate that the firms with higher NPD-orientation have also higher pay-off in terms of novelty of new products developed, while the firms in this group are also much less active in modifying existing products. On the whole, 59\% of all new products were developed by the firms having long-term NPD objectives. These results confirm the fact that the collaboration profile of these firms also contributes to successful development of new products.

Table 5 Way of NPD and type of product innovation

\begin{tabular}{|c|c|c|c|c|c|}
\hline & \multicolumn{5}{|c|}{$\begin{array}{c}\text { Type of product innovation, } \begin{array}{c}\% \text { of cases in each category of product } \\
\text { innovation }\end{array} \\
\text {. }\end{array}$} \\
\hline & $\begin{array}{l}\text { New for the } \\
\text { firm, \% }\end{array}$ & $\begin{array}{l}\text { New for the } \\
\text { domestic } \\
\text { market, \% }\end{array}$ & $\begin{array}{l}\text { New for the } \\
\text { industry, \% }\end{array}$ & $\begin{array}{c}\text { Modification } \\
\text { of existing } \\
\text { products, \% }\end{array}$ & $\begin{array}{l}\text { All new } \\
\text { products, \% }\end{array}$ \\
\hline $\begin{array}{l}\text { High importance } \\
\text { of NPD aims }\end{array}$ & 64.3 & 58.5 & 66.7 & 32 & 59 \\
\hline $\begin{array}{l}\text { Low importance } \\
\text { of NPD aims }\end{array}$ & 35.7 & 41.5 & 33.3 & 68 & 41 \\
\hline
\end{tabular}

\section{Conclusions}

As discussed above, a number of factors affect the role of collaborative approach in NPD. A resource-based perspective, shared values and strategic aims are important drivers for collaboration and facilitators of NPD success. The barriers of collaborative NPD are closely linked to conflicts between parties and risk perception. The context of the Russian economy, as supported by existing research on collaboration practices, provides additional difficulties for building successful and mutually beneficial partnerships.

We implied that long-term strategic aims in the field of product innovation, ability to develop radically new products, and the type of NPD strategy will help explain the role external partners play in developing product innovations in Russian firms. Two main propositions were illustrated by the results of an empirical study.

The results indicated a certain relationship between the importance of NPD-related aims for the firm, the type of product innovation and the pattern of collaboration with external partners on NPD. The type of product innovation and the importance of strategic NPD aims had affected the frequency of collaboration with a particular group of partners.

Radically new products, as supported by the empirical evidence, require prioritisation of NPD-related strategic aims, such as NPD leadership, time-to-market reduction, and time of NPD reduction. Firms focusing on product innovation development perform better in terms of the level of novelty of new products than products new for the market or for the industry in the whole. They also have a different pattern of involving external partners in NPD collaboration: a more open and more intensive approach to external partnerships is selected. NPD-intensive firms are better at collaboration with international partners - customers, suppliers and partners in joint ventures. The learning effects potentially arising from such collaboration may strengthen the advantage created and facilitate further improvement of the firm's competitiveness both in the domestic and 
international market. Identification of the cluster of NPD-intensive firms is one of the contributions of the study, providing foundation for further investigation of the motives, modes and drivers of such collaboration.

Another contribution is the finding that Russian firms apply a portfolio approach to both NPD strategy selection and partner selection. Thus, in most cases, successful firms use both an in-house and a collaborative NPD strategy. They also have a network of external partners involved in product innovation. Coordination of the new product portfolio and network of external partners can indicate development of certain organisational competencies in the field of NPD, networking and interfirm collaboration, which can imply potential for advantage creation.

NPD-oriented Russian firms illustrated higher readiness for multi-stakeholder collaboration, including international partners, indicating their ability to coordinate international collaboration. Although the same collaborative product innovation barriers might arise and have a negative effect on the interaction between the partners, a better level of relational capability development could potentially reduce the risks of failure. The firms identified in the study as firms with high NPD-orientation and able to produce market level and industry level innovations would thus be the primary potential partners for domestic and international collaboration.

The results of data analysis raise research questions for further investigation. Is there a positive effect on business performance by the selected strategy of collaboration with external partners in the NPD process? Has the number of external partners involved any effect on how successful their involvement in developing new products is? Which factors dominate the collaboration patterns - push or pull factors? These questions require a more detailed and in-depth analysis of the way Russian firms collaborate with external partners when developing new products.

\section{References}

Amaldoss, W. and Rapoport, A. (2005) 'Collaborative product and market development: theoretical implications and experimental evidence’, Marketing Science, Vol. 24, No. 3, pp.396-414.

Anderson, J.C. and Narus, J.A. (1990) 'A model of distributor firm and manufacturer firm working partnerships’, Journal of Marketing, Vol. 54, pp.42-58.

Appleyard, M.M. (2003) 'The influence of knowledge accumulation on buyer-supplier co-development projects', Journal of Product Innovation Management, Vol. 20, pp.356-373.

Berger, Ch., Möslein, K., Piller, R. and Reichwald, F. (2005) 'Co-designing modes of cooperation at the customer interface: learning from exploratory research', European Management Review, Vol. 2, pp.70-87.

Berthon, P., Hulbert, J.M. and Pitt, L.F. (1999) 'To serve or to create', California Management Review, Vol. 42, pp.37-58.

Biemans, W.G. (1992) Managing Innovations within Networks, Routledge, London.

Bjelland, O.M. and Wood, R.Ch. (2008) ‘An inside view of IBM’s 'Innovation Jam’, MIT Sloan Management Review, Vol. 50, No. 1, pp.31-40.

Bonney, L., Clark, R., Collins, R. and Fearne, A. (2007) 'From serendipity to sustainable competitive advantage: insights from Houston's farm and their journey of co-innovation', Supply Chain Management: An International Journal, Vol. 12, No. 6, pp.395-399.

Botazzi, L. and Giovanni, P. (2003) 'Innovation and spillovers in regions: evidence from European patent data', European Economic Review, Vol. 47, pp.687-710.

Bull, A. (1993) Entrepreneurial Textile Communities, Chapman \& Hall, London. 
Child, J. and Faulkner, D. (1998) Strategies of cooperation: Managing Alliances, Networks, and Joint Ventures, Oxford University Press, Oxford and New York.

Clark, K.B. and Fujimoto, T. (1991) Product Development Performance, Harvard Business School Press, Boston.

Cunningham, M. and Ford, D. (1993) 'Technology, networks and purchasing strategy', Industrial Networks: Advances in International Marketing, Vol. 5, pp.205-219.

Day, G.S. and Wensley, R. (1988) 'Assessing advantage: a framework for diagnosing competitive superiority', Journal of Marketing, Vol. 52, pp.1-20.

Deck, M. and Strom, M. (2002) 'Model of co-development emerges', Research Technology Management, Vol. 45, No. 3, pp.47-54.

Dodgson, M. (1993) Technological Collaboration in Industry, Routledge, London.

Dyer, J.H. and Singh, H. (1998) 'The relational view: cooperative strategy and sources of interorganizational competitive advantage’, Academy of Management Review, Vol. 23, No. 4, pp.660-679.

Elias, A.A., Cavana, Jackson, R.Y. and Jackson, L.S. (2002) 'Stakeholders analysis for R\&D project management', $R \& D$ Management, Vol. 3, No. 4, pp.301-310.

Fowler, D.R. (1984) 'University-industry research relationships', Research Management, January-February, Vol. 27, No. 1, pp.35-41.

Foxall, G.R. (1989) 'User initiated product innovations', Industrial Marketing Management, Vol. 18, pp.95-104.

Foxall, G.R. (1994) 'Consumer initiators: adaptors and innovators', British Journal of Management, Vol. 5, pp.3-12.

Freeman, C. (1982) The Economics of Industrial Innovation, Frances Pinter, London.

Freeman, C. and Hagedoorn, J. (1994) 'Catching up or falling behind: patterns in international inter-firm technology partnering', World Development, Vol. 22, pp.771-780.

Gemünden, H.G., Ritter, T., et al. (1996) 'Network configuration and innovation success: an empirical analysis in German high-tech industries', International Journal of Research in Marketing, Vol. 13, pp.449-462.

Georghiou, L., Metcalfe, J.S., et al. (1986) Post-Innovation Performance: Technological Development and Competition, The Macmillan Press Ltd., London.

Gobeli, D.H. and Brown, D.J. (1987) 'Analyzing product innovations', Research Management, July-August, pp.25-31.

Håkansson, H. (1989) Corporate Technological Behaviour - Cooperation and Networks, Routledge, London.

Håkansson, H. and Eriksson, A.K. (1993) 'Getting innovations out of supplier networks’, Journal of Business-to-Business Marketing, Vol. 1, No. 3, pp.3-34.

Hart, S.L. and Sharma, S. (2004) 'Engaging fringe stakeholders for competitive imagination', Academy of Management Executive, Vol. 18, No. 1, pp.7-18.

Hutt, M.D., Stafford, E.R. and Walker, B.A. (2000) 'Case study defining the social network of a strategic alliance’, Sloan Management Review, Vol. 41, No. 2, pp.51-62.

Jansson, H., Johanson, M. and Ramstroem, J. (2007) 'Institutions and business networks: a comparative analysis of the Chinese, Russian, and West European markets', Industrial Marketing Management, Vol. 36, pp.955-967.

Jassawalla, A.R. and Sashittal, H.C. (2003) 'Building collaborative new product processes: why instituting teams is not enough’, SAM Advanced Management Journal, Vol. 68, No. 1, pp.27-36.

Johanson, M. (2008) 'Institutions, exchange and trust: a study of the Russian transition to a market economy', Journal of International Management, Vol. 14, pp.46-64.

Johnson, W.H.A. and Filippini, R. (2009) 'Internal vs. external collaboration: what works', Research report, Industrial Research Institute, May-June, pp.15-17. 
Kaartemo, V. (2009) Russian Innovation System in International Comparison - The Bric Countries in Focus, Electronic Publications of Pan-European Institute 22/2009.

Kadochnikov, S., Essine, P. and Slobodyan, S. (2003) 'What forces Russian firms to increase product variety: FDI or competition from import?’, Policy Brief, No. 1, pp.1-2.

Kadochnikov, S., Essine, P. and Slobodyan, S. (2004) 'What explains the product differentiation of Russian companies: competitive pressure or technological spillovers?', Policy Brief, No. 3, pp.1-3.

Kayis, B., Zhou, M., Savci, S., Khoo, Y.B., Ahmed, A., Kusumo, R. and Rispler, A. (2007) 'I'RMAS - development of a risk management tool for collaborative multi-site, multi-partner new product development projects', Journal of Manufacturing Technology Management, Vol. 18, No. 4, pp.387-414.

Kleinsmann, M. and Valkenburg, R. (2005) 'Learning from collaborative new product development projects', Journal of Workplace Learning, Vol. 17, No. 3, pp.146-156.

Koponen, T. (2009) 'Opportunities of Finland in Russian innovation environment', Bimonthly Review, Expert article 382, No. 4, p.2.

Kotabe, M. and Swan, K.S. (1995) 'The role of strategic alliances in high-technology new product development', Strategic Management Journal, Vol. 16, pp.621-636.

Lam, P-K., Chin, K-S., Yang, J-B. and Liang, W. (2007) 'Self-assessment of conflict management in client-supplier collaborative new product development', Industrial Management \& Data Systems, Vol. 107, No. 5, pp.688-714.

Luecke, R. and Katz, R. (2003) Managing Creativity and Innovation, Harvard Business School Press, Boston, MA.

Marshall, C. (2004) 'The dynamic nature of innovation partnering: a longitudinal study of collaborative interorganizational relationships', European Journal of Innovation Management, Vol. 7, No. 2, pp.128-140.

McIvor, R. and Humphreys, P. (2004) 'Early supplier involvement in the design process: lessons from the electronics industry', Omega, Vol. 32, No. 3, pp.179-199.

Meyers, P.W. and Athaide, G.A. (1991) 'Strategic mutual learning between producing and buying firms during product innovation', Journal of Product Innovation Management, Vol. 8, pp.155-169.

Noori, H. (1990) Managing the Dynamics of New Technology: Issues in Manufacturing Management, Prentice Hall, Englewood Cliffs, NJ.

Parkinson, S.T. (1985) 'Factors influencing buyer-seller relationships in the market for high-technology products', Journal of Business Research, Vol. 13, pp.49-60.

Parung, J. and Bititci, U.S. (2008) 'A metric for collaborative networks', Business Process Management, Vol. 14, No. 5, pp.654-674.

Ring, P.S. and Van de Ven, A.H. (1994) 'Development processes of cooperative interorganizational relationships', Academy of Management Review, Vol. 19, No. 1, pp.90-118.

Rothwell, R. (1991) 'External networking and innovation in small and medium-sized manufacturing firms in Europe’, Technovation, Vol. 11, No. 2, pp.93-112.

Rothwell, R. (1992) 'Successful industrial innovation: critical factors for the $1990 \mathrm{~s}$ ', $R \& D$ Management, Vol. 22, No. 3, pp.221-239.

Roud, V. (2007) 'Firm-level research on innovation and productivity: Russian experience', MEIDE Papers, p.10.

Salmi, A. (2004) 'Institutional change of business networks: Russian transition revisited', Proceedings, 20th IMP Conference, Copenhagen, Denmark.

Sarin, S. and Mahajan, V. (2001) 'The effect of reward structures on the performance of cross-functional product development teams', Journal of Marketing, Vol. 65, No. 2, pp.35-53.

Schaffer, M. and Kuznetsov, B. (2007) 'Productivity', in Desai, M., et al. (Eds.): Enhancing Russia's Competitiveness and Innovative Capacity, No. 2, The World Bank, Washington DC. 
Serrano, V. and Fischer, T. (2007) 'Collaborative innovation in ubiquitous systems', Journal of Intellectual Manufacturing, Vol. 18, pp.599-615.

Seshasai, S. and Gupta, A. (2009) '24-hour knowledge factory paradigm and its role in IT collaboration', Journal of Information Technology Case and Application Research, Vol. 11, No. 4, pp.11-29.

Smith, P.G. and Blanck, E.L. (2002) 'From experience: leading dispersed teams', Journal of Product Innovation Management, Vol. 19, No. 4, pp.294-304.

Swink, M. (2006) 'Building collaborative innovation capability', Research Technology Management, Vol. 49, No. 2, pp.37-48.

Teece, D.J. (1986) 'Profiting from technological innovation: implications for integration, collaboration, licensing and public policy’, Research Policy, Vol. 15, pp.285-305.

Torkkeli, M., Podmetina, D. and Väätänen, J. (2009) 'Knowledge absorption in emerging economy - role of foreign investments and trade flows in Russia', International Journal of Business Excellence, Vol. 2, Nos. 3-4, pp.269-284.

Ulaga, W. and Eggert, A. (2003) 'Relationship value in business markets: development of a measurement scale', ISBM Report 2-2003, Institute for the Study of Business Markets, The Pennsylvania State University.

Uzzi, B. (1997) 'Social structure and competition in interfirm networks: the paradox of embeddedness', Admin. Sci. Quart., Vol. 42, pp.35-67.

von der Heidt, T. (2008) 'Developing and testing a model of cooperative interorganisational relationships (IORs) in product innovation in an Australian manufacturing context: a multi-stakeholder perspective', A thesis submitted in fulfilment of the requirements for the Degree of Doctor of Philosophy, School of Commerce and Management, Southern Cross University, Australia

von Hippel, E. (1988) The Sources of Innovation, Oxford University Press, New York.

Walter, A., Auer, M. and Ritter, Th. (2006) 'The impact of network capabilities and entrepreneurial orientation on university spin-off performance', Journal of Business Venturing, Vol. 21, No. 4, pp.541-567.

Walter, A., Ritter, T. and Gemünden, H.G. (2011) 'Value creation in buyer-seller relationships', Industrial Marketing Management, Vol. 30, pp.365-377.

Yli-Renko, H., Autio, E., et al. (2001) 'Social capital, knowledge acquisition and knowledge exploitation in young technology-based firms', Strategic Management Journal, Vol. 22, pp.587-613. 